\title{
İletişim Fakültesi Öğrencilerinin Sahte/Yalan Haberlerle İlgili Görüşlerine Yönelik Betimleyici Bir Çalıșma
}

\section{- Selman Selim Akyüz}

Dr. Öğr. Üyesi Selçuk

Üniversitesi

selmanselimakyuz@hotmail.co $\mathrm{m}$

ORCID ID: 0000-0003-09327897

- Mete Kazaz

Doç. Dr. Selçuk Üniversitesi kazazmete@gmail.com ORCID ID: 0000-0002-03671091

\section{- Birol Gülnar}

Prof. Dr. Selçuk Üniversitesi bgulnar@yahoo.com ORCID ID: 0000-0002-71141500

\section{ÖZET}

Iletişimde dijitalleşmenin başlamasıyla birlikte haberin üretim, dă̆ıtım ve tüketim şekilleri de köklü bir değişime uğramıştır. Geleneksel medya günden güne güç kaybederken, internet ve sosyal medyayı kapsayacak şekilde bir medya adlandirmast olan "yeni medya", tüketicinin, haberin üreticisi ve aynı zamanda dağıtıcısı durumuna gelmesine neden olmuştur. Üretim süreçlerindeki profesyonel ve klasik anlayışın sarsılması haber güvenilirliğinde önemli sorunları ortaya çıkarmıştır. Bu sorunların başında kontrol mekanizmalarının işlememesi nedeniyle yanlış bilgi sahte ya da yalan haber gelmektedir. Yeni medyada üretilen içerikler doğrudan tüketiciye ulaşmakta, doğruluğu kontrol edilemeyen bu bilgi ve haberler, gerçeğin "bükülmesine" neden olmaktadır.

$\mathrm{Bu}$ çalışmada, üniversite öğrencilerinin yeni medyayı hangi amaçlarla kullandıkları, yanlış bilgiye karşı tutum geliş̧tirip geliştirmedikleri, yanlış bilgi ya da sahtelyalan haberlerin üretimi, dolaşımı ve tüketimiyle ilgili görüs ve davranışlarının neler olduğu belirlenmeye çalıșlmıștır. Yapılan saha araștırması sonunda, üniversite ögrencilerinin geleneksel medyayl tarafl bulduğu, haberleri sosyal medya ve internet sitelerinden tükettiği, sosyal medyada haber paylaşımından kaçınırken, kapalı mesajlaşma uygulamalarına daha fazla ilgi gösterdiği belirlenmiştir. En fazla siyaset ve güvenlik haberlerinden şüphe duyulurken sahte haberlere inanma sebepleri konusunda "araştırma yapmaktan kaçınma" ve "siyasi kutuplaşma” gösterilmektedir.

Anahtar Sözcükler: Sosyal Medya, Yanlıș Bilgi, Sahte Haber, Yalan Haber, Üniversite Öğrencileri. 


\section{A Descriptive Study on The Views of Students of Communication Faculty about Fake News}

\section{- Selman Selim Akyüz} Asst. Prof. Selcuk University selmanselimakyuz@hotmail.c om

ORCID ID: 0000-0003-09327897

- Mete Kazaz

Assoc. Prof. Selcuk

University

kazazmete@gmail.com

ORCID ID: 0000-0002-03671091

- Birol Gülnar

Prof. Dr. Selcuk University

bgulnar@yahoo.com

ORCID ID: 0000-0002-71141500

\begin{abstract}
With the onset of digitalization in communication the production, distribution and consumption patterns of news are undergoing a radical change. While traditional media is losing power day by day, new media, a media designation to cover the internet and social media, has led the consumer to become the producer and distributor of news at the same time. The shake-up of the professional and classical understanding in the production processes has revealed significant problems in news reliability. Misinformation and fake news have become major problems due to the disruption of the news control mechanism. The content produced in new media reaches the consumer directly and this information and news whose accuracy cannot be controlled causes the "contortion" of the truth.The aim of this study was to determine the views and behaviors of university students regarding the use of new media, their attitudes towards misinformation, the production, circulation and consumption of misinformation or fake news. At the end of the field survey, students of communication faculty found traditional media biased, consumed news from social media and websites, while avoiding news sharing on social media, showed more interest in closed messaging applications. "Avoidance of research" and "political polarization" are cited in the reasons for believing fake news while most doubt politics and security news.
\end{abstract}

Keywords: Social Media, Misinformation, Fake News, False News, University Students. 


\section{GİRIŞ}

Geleneksel medya olarak tanımlanan gazete, televizyon gibi araçların medyanın merkezinde olduğu uzun dönemde, önemli etik sorunlar arasında yer alan ve yanlış bilgi, manipülasyon, dezenformasyon, propaganda, asparagas haber şeklinde tanımlanan olgular, medyanın "yenilenmesiyle" birlikte yeni formlar alarak tartışılmaya devam etmektedir.

Yeni medyanın kolay ulaşılabilir ve kullanıcıyı içerik üretimine dahil eden yapısı, büyük bir içerik artışına neden olurken mecranın bütünleşik yapısı, içeriklerin daha hızlı ve kolay dağıtımını beraberinde getirmiştir. Geleneksel medya, internet ve sosyal medyaya adapte olmaya çalışırken dijitalleşmiş bu alanın dijital kimlikli ya da dijitalde doğmuş içerik üreticileri de hızla artmıştır. Artık haberler sadece geleneksel medyanın profesyoneller tarafından üretilmiş içeriklerden değil kullanıcıların merkezde olduğu yeni medyadan da takip edilmektedir (Reuters Digital News Report, 2020).

Kişiselleştirilmiş haber uygulamaları ile istemediği haberlere maruz kalmayan kullanıcılar, alternatif bir medya alanı oluşturma isteğini hayata geçirebilmektedir (Narin, 2018, s. 237). Ancak bu süreç özellikle haber üretiminde geleneksel yöntemlerin terk edilmesine, doğruluk kontrolü süreçlerinin zayıflamasına, hatta ortadan kalkmasına neden olmakta, alanın kötücül amaçlar için kullanılması siyasi ve ideolojik kutuplaşmayı arttırmaktadır.

Uluslararası organizasyonlar, sivil toplum kuruluşları, hükümetler ve sosyal medya platformları, dezenformasyon ile mücadeleyi iletişim politikalarında öncelikleri arasına almaktadır. Facebook, her yıl sitesindeki yalan haberlerin tespiti için doğruluk kontrolü organizasyonlarına (Fact checking organization) milyonlarca dolar ödeme yapmaktadır (Rupar, 2019).

Yalan haberlerle ilgili; üretim ve dolaşıma sokulmasının yanı sıra bu haberlerin neden daha hızlı yayıldığı, kullanıcıların neden bu haberlere ilgi gösterdiği de birçok çalışmanın konusu olmuştur. Çünkü üretiminden daha çok bu haberlerin kitleye, kullanıcılara ulaşması ve bunun kullanıcılar aracılığıyla yayılması önem taşımaktadır. 
Bu nedenle çalışmada, kullanıcıların yeni medyayı kullanma alışkanlıkları, sahte/yalan haberle ilgili bilgi düzeyleri, geleneksel ve yeni medyada sahte haberle karşılaşma ve sahte haber konuları ve sahte haberlere inanma noktasında bilinç düzeyleri ölçülmeye çalışılmıştır.

Çalışmada, nicel araştırma yöntemlerinden saha araştırması uygulanmış, Selçuk Üniversitesi İletişim Fakültesi’nde eğitim gören 313 öğrenci ile yüz yüze anket yapılmıştır.

\section{YENI MEDYA VE SAHTE HABER/YANLIŞ BİLGI SORUNU}

İletişimin önemli ölçüde değişime uğradığ̀ ve gerçeğin tanımının değiştiği dönemi anlatmak için kullanılan "Hakikat Ötesi Çağ” (Post Truth) ifadesi (Keyes, 2019), gerçeğin kanıtlarla, bilgiyle değil algıyla, bakış açısıyla, fayda-zarar ilişkisiyle değerlendirildiği bu yeni dönem için önemli bir tanım haline gelmiştir. Keyes, tanımla aynı adı taşıyan çalışmasında, insanlık tarihi boyunca yalan ve aldatmanın nedenlerine odaklanırken, günümüz dünyasında "hakikatin yerini inanılabilirliğin aldığını" aktarmaktadır. Siberuzay yalan söylemeyi ve yaymayı kolaylaştıran yapısı ile sahtekarlığın yaptırım değil teşvikle karşılaştığı "etikten muaf bir bölge" halini almıştır (Keyes, 2019, s. 9, 259).

Yeni Medya, günümüzde medyadaki dijitalleşmeyle birlikte elektronik ortamlarda yapılan yayıncılığın tümüne verilen addır. Teknolojinin imkanlarıyla etkileşim, ulaşılabilirlik, kaynak çeşitliliği, geçişkenlik, etkinlik ve düzenleme gibi geleneksel medyadan farklı özellikleri bulunan yeni medyanın en önemli özelliği kullanıcıyı içerik ve haber üretim süreçlerine dahil etmesidir (Kazaz \& Akyüz, 2019, s. 29, 31).

Yalan haber ve yanlış bilgi sorununun yeni medyaya özel olarak adlandırılması ve tartışılmasınının nedeni de bu farklı özellikleridir.

İnternet ve sosyal medyada yanlış bilgi sorunuyla birlikte kullanımı artan "sahte haber" ifadesi Türkçe’ye “Fake News” şeklindeki İngilizce tanımlamadan aktarılmıştır. "Genellikle politik görüşler üzerinde etki yaratmak amacıyla internet ya da diğer medyayı kullanarak yayılan haber gibi görünen düzmece, sahte hikâyeler" olarak tanımlanan (Cambridge Dictionary) bu olgu, Türkçe'de yalan haber kavramıyla yer edinmiştir.

Diğer yandan sorun sadece haber ekosisteminde alanında olmadığı için "yanlış bilgi" ifadesi de daha kapsayıcı bir tanım olarak kullanılmaktadır. Bunun için yanlış bilginin türleriyle, üretilme, yayılma, neden ve amaçlarına da odaklanmak gerekmektedir. 
Yanlış bilginin kasıtlı olarak üretilip yayılması kötücül kullanımın bir sonucu olarak dezenformasyon şeklinde adlandırılmaktadır. "Misinformation” şeklindeki İngilizce ifadeyle ise fabrikasyon/sahte olduğu bilinmeden yanlış bilginin ortaya çıkması ve yayılmasına neden olunması kastedilmektedir. Claire Wardle (2020) yalan haber tanımının içine kasıt olmaksızın üretimi ve yayılmasına neden olunan haberleri almazken zarar verme amacı olmayan parodi haberleri ise bu kapsamda değerlendirmiştir. Allcott ve Gentzkow da (2017, s. 213), haberlerin zarar verme amaciyla kasıtlı olarak üretilmesini önemli bir tanımlama kriter olarak göstermektedir. Dolayısıyla yanlış bilgi tüm iletişim alanını kapsayan bir tanımlama için uygun görülebilir ancak temel tanımlamalar ve tartışmaların yönü sahte/yalan haber ve yanlış bilgi ifadelerinin birbirlerini içerecek şekilde kullanılabildiğini göstermektedir.

Yalan haberlerin türleri de tanım sayısını arttıran bir diğer özelliktir. "Sahte Haber” adlı kitabın yazarları Kazaz ve Akyüz de (2019, s. 47, 56), üretme yöntemlerinden yola çıkarak sahte haberlerin türlerini ortaya koymuştur. Buna göre, internet ve sosyal medyada 7 yöntemin sıklıkla sahte haber üretmekte kullanıldığını ortaya koymuşlardır:

- Ekleme ya da çıkarma yaparak bir bilgiyi çarpıtma,

- Gerçek bir kaynak ya da haber kuruluşuna dayandırarak haber üretme,

- Sahte kaynak ya da sahte kuruluşlara dayandırarak haber üretme,

- Gerçek görseller üzerinde montaj/oynama yaparak haber üretme,

- Farklı olayların görsellerini kullanarak ilişki/bağlam oluşturma,

- Kontra-Ters kimlikli sahte kullanıcılar üzerinden haber üretme (Asimetrik propaganda)

- Herhangi bir kaynağa dayandırmadan, anonim haber üretme.

Dolayısıyla yalan/sahte haber, şekil olarak olarak habere benzemekle birlikte, kasıtlı ya da kasıtsız olarak yanlış bilgiler barındıran ya da yeni bir bağlam oluşturulan içeriklerden oluşmaktadır (Kocabay Şener, 2018, s. 355). Yeni medyanın bir parçası olan internet siteleri ve bloglar, sahte/yalan haberlerin üretildiği mecralar arasındadır ancak bu içeriklerin en çok üretildiği ve yayıldığı alanlar sosyal medya platformlarıdır. 
Görsel 1: 2019 Yerel Seçimlerinde sahte haberlerin mecralardaki yaygınlı̆̆g

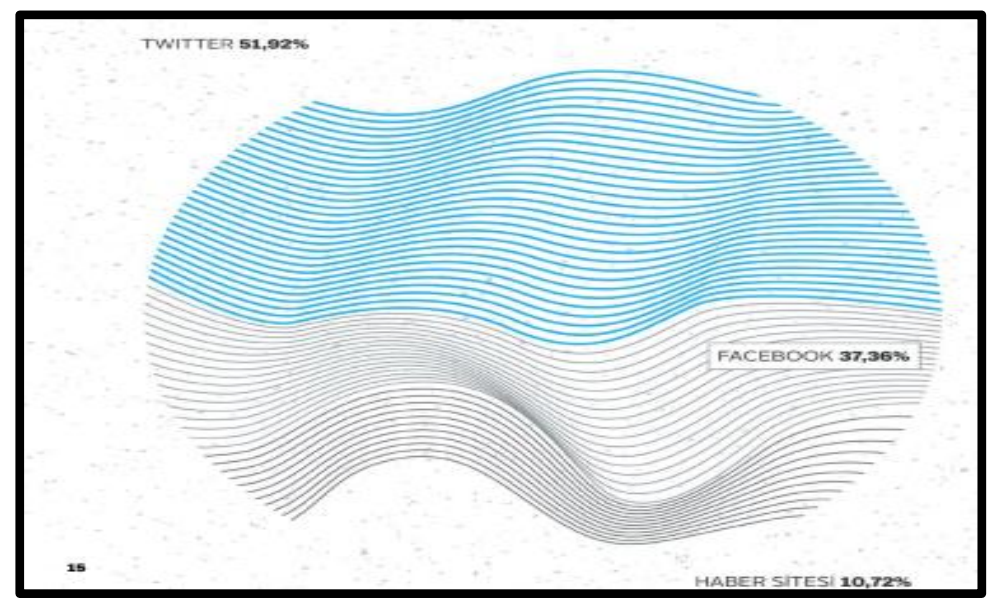

Facebook ve Twitter bu anlamda baş1 çekerken (Foça, 2019, s. 15) son dönemde Whatsapp gibi mesajlaşma uygulamaları, sahte haberlerin yayılmasında öne çıkmaya başlamıştır. COVID-19 Salgını döneminde üretilen ve yoğun şekilde paylaşılan komplo teorileri ve yalan haberler nedeniyle Whatsapp, Dünya Sağl1k Örgütü (DSÖ) ve sivil toplum kuruluşlarıyla birlikte çalışarak mesajların iletimine sınır getirmiş ve kısa sürede viral mesajların paylaşımında yüzde 70 azalma görülmüştür (digitalreport.com.tr).

\section{YALAN HABERLER VE KULLANICILAR ÜZERİNDEKİ ETKILLEİ}

Yalan haberlerin, sadece internet kullanıcıları ya da küçük gruplar tarafından değil, geleneksel medya kuruluşları, çeşitli şirketler ve fonlanmış ya da gönüllü troller aracılığıyla da farklı amaçlarla yayılabildiği bilinmektedir (Ünal \& Taylan, 2017, s. 81).

“İnanılabilir yalanlar”, yeni medyada haber güvenilirliğinin, kanaatlerin manipüle edilmesinin ötesine geçerek insanların can güvenliğini tehdit eder boyutlara da ulaşabilmektedir. Türkçe'de sıklıkla kullanılan “yalandan kimsenin ölmediği” sözünün yanlışlı̆̆ı sık sık teyit edilmektedir. Koronavirüs (COVID-19) Salgını döneminde yapılan sahte haberler nedeniyle İran'da hastalıktan korunmak için sahte alkol içen yaklaşık 800 kişi hayatını kaybetmiştir (Güler, 2020). Komplo teorileri ya da inançları nedeniyle hastalığı hafife alarak önlemlere uymayarak virüse yakalanan ve hayatını kaybeden ABD'li Rahip de, bu dönemde önemli bir örnek olarak haberlere yansımıştır (Boorstein, 2020). 
Örnekler yeni ancak sosyal medya aracılığıyla üretilen ve yayılan yanlış bilgiler, son 10 yıllık süreçte birçok seçimlerin de en önemli tartışmaları arasında yer almıştır. ABD seçimlerine Rusya ve trol birliklerinin etkisi ile İngiltere'nin Brexit ile Avrupa Birliğinden çıkmasında yalan haberlerin rolü, haber güvenilirliğinin ne kadar önemli bir sorunla karşı karşıya olduğunu göstermesi açısından önemli örneklerdir (Pomerantsev, 2019). Bu örnekler sahte/yalan haberlerin kimler tarafından üretildiği konusunda da fikir vermektedir. Yeni medyanın içerik üreticisi haline gelen "sıradan" kullanıcıların yanı sıra, hükümetler, istihbarat örgütleri, ideolojik ve siyasi gruplar ve özel şirketler dezenformasyon sürecinin önemli aktörleridir (Kazaz \& Akyüz, 2019, s. 112).

Gerek profesyonel haber merkezlerine sahip geleneksel medyanın, gerekse yeni medyadaki kullanıcıların ürettiği yalan haberlerin dijital ağlarda hızla dolaşıma girmesinin nedenleri arasında sadece eleştirel düşünce eksikliği gösterilmemektedir (Taş \& Taş, 2018, s. 204).

İdeolojik yanlılıklar ve kutuplaşmanın keskinleşmesi, geleneksel haber kaynaklarının siyasallaşması ve habere duyulan güvenin giderek azalması, araştırma isteksizliği, yeni medyanın kullanıcılara sağladığı görece özgürlük (gerçek kimliğe gerek olmadan kullanılabilmesi), dijital mecraların filtre ve algoritmaları ile bunların sonucunda oluşan yankı odaları, yalan haberlerin üretim ve yayılımını arttıran etkenler arasında sayılmaktadır.

Bahsettiğimiz bu etkenlerin önemli bir bölümü, medya mesajlarının tüketiminde bilişsel yanlılıkların, önyargıların, önceki kanaatlerin rolüne işaret etmektedir.

Haber ya da iletişim döngüsünü yeni medya ile birlikte yanlış bilginin üretim ve dolaşımına açık hale getiren üç tür yanlılık belirlenmiştir: Bilişsel yanlılıklar, toplumdaki yanlılıklar ve algoritmaya bağlı yanlılıklar.

Yalan haberle etkileşime girilmesi sürecindeki bu yanlılıkları ortaya koyan Ciampaglia ve Menczer'e göre (2018), bilişsel yanlılık, beynin bilgiyi işlemek için kullandığı olağan süreçlerle üretilmektedir. Beyin çok fazla uyarana maruz kaldığında fazla bilgi yüklemesini önlemek adına bazı kısayollar kullanmaktadır. Genelde beynin rutin işleyişini düzenleyen bu bilişsel kısayollar, sosyal medyada karşılaşılan bir içeriğin okunması, paylaşılması ya da yorumlanıp yorumlanmamasına karar verme aşamasında etkili olmaktadır. Metnin 
doğruluğuna, kim tarafından yazıldığına ilişkin bir bilgi sunmamasına rağmen insanlar, başlıkların yarattığı duygusal çağrışımlardan oldukça etkilenmektedir.

Bir diğer yanlılık nedeni ise toplumsal grupların oluşmasındaki doğal süreçler olarak görülmektedir. Bir Twitter kullanıcısının politik eğilimleri takipleştiği kimselerin siyasi tercihlerine bakarak kolayca belirlenebilmektedir. Araştırmacılar, grupların ideolojik görüş odağında kümelendikleri ve aynı görüşü paylaşmayanları dışarıda bıraktıkları "yankı fanusları"nın (eco chambers), doğruluğu önemli olmaksızın, bilgiyi yaymada etkili olduğunu aktarmaktadir.

Yank1 Odası/Fanusu terimi, politik olarak sadece belirli fikirlerin ve inançların paylaşıldığı bir durumu ifade etmek için kullanılmaktadır. Fikirlerin ve bilgilerin serbest dolaşımı olmadan, yankı odasının içindeki insanlar var olan her şeyin yalnıza maruz kaldıklarından ibaret olduğuna inanabilmektedir (Dubois, 2018, s. 729).

Kullanıcıların çevrimiçi platformlarda ne göreceklerini tavsiye eden ya da belirleyen algoritmalar süreçte rol oynamaktadır. Bu kişiselleştirme teknolojileri, her bir kullanıcının ilgi duyduğu mesajları tespit ederek, ilgi duyabileceği başka mesaj ve haber kaynaklarını düzenlemektedir. Fakat bu eleme süreci, kullanıcıların bilişsel ve sosyal önyargılarının pekişmesine neden olabilmektedir.

Bilişsel yanlılığa neden olan etkenlerden en dikkat çekeni, yankı fanusu/odası olarak tanımlanan kapalı iletişim topluluklarıdır. Türkiye'de siyasi tartışmaların ve gündemin daha sık takip edildiği ve dolayısıyla belirlendiği Twitter'da (Kılıç, 2020, s. 125), ideolojik ve siyasi hareketlerin üyelerini bir araya getirmek için "birbirlerini takip etme" kampanyaları yapılmaktadır. Son olarak 2020 yılı Mayıs ayında Cumhurbaşkanı Erdoğan'ın çağrısıyla (Uğur, 2020) başlatılan \#MilliHesaplarYanyana kampanyasında, milyonlarca kullanıcı birbirini takip ederek sosyal medyada örgütlenmelerini güçlendirmeye çalışmıştır (twitter.com). 
Görsel 2: Twitter'da başlatılan karşılıklı takip kampanyasına ait bir paylaşım

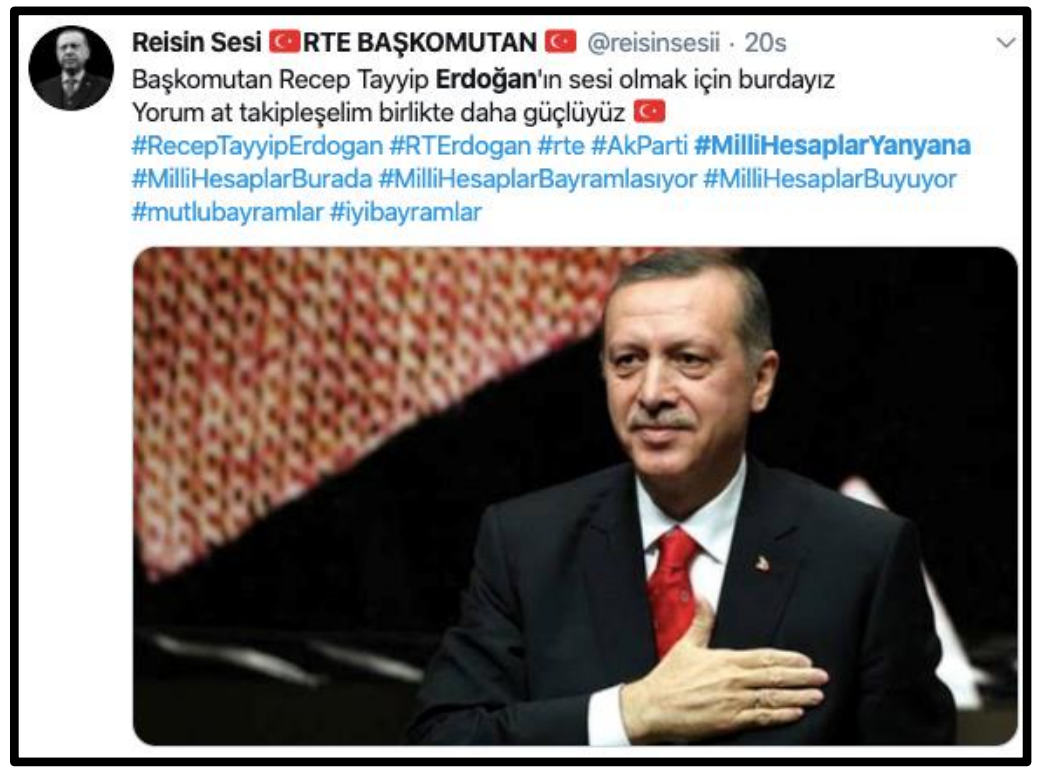

Ancak bu tür karşılıklı takipleşme ve yalnızca kendi siyasi çevresinden kişilerin mesajlarını paylaşma aktiviteleri; yankı odaları oluşturarak farklı görüşlerle karşılaşmamaya, algoritmaların daha da sıkı filtreler geliştirmesine ve siyasi/ideolojik görüşlerin katılaşmasına neden olmaktadır.

Diğer yandan, yankı fanuslarının kutuplaşmadan beslenip kutuplaşmayı arttırdığı gibi yalan haberlerin viralleşmesini de sınırlandırdığı yönünde çalışmalar bulunmaktadır (Törnberg, 2018, s. 17). Bazı araştırmalar, algoritmalar yoluyla kişiselleştirilen bilgi akışı çemberlerinden, doğrulama girişimleri ve arama motorları sayesinde belirli ölçülerde çıkılabildiğini gösterse de sıradan yeni medya kullanıcılarının dijital okuryazarlık becerilerinin zayıf olması, sorunun halen çözüm beklediğini göstermektedir (Narin, 2018, s. 246).

Yanlış bilginin yanlış bilgiye inanmaya ve paylaşmaya yatkın olanların daha çok yaşça büyük bireyler olduğunu ortaya koyan araştırmalar bulunmaktadır. Gençlerin eğitim ve dijital okuryazarlık düzeyinin yüksek olması savunma mekanizmalarını güçlendirmektedir. Ayrıca yaşl1ların kendi fikirlerine bağlılıkları daha güçlü olduğu değerlendirilmektedir. Doğrulama platformları Full Fact, Africa Check ve Chequedo tarafindan yapılan ve bu bulguları ortaya koyan araştırmaya göre (2020, s. 4), yalan haberlerin yayılmasında, mesajların duygulara ve desteklenen fikirlere yakınlığı, aynı içeriklerle çok sık karşılaşılması yani şüpheli içeriklerin birçok kullanıcı tarafından paylaşılması gibi etkenler öne çıkmaktadır. 
Sahte/yalan haber ya da yanlış bilgiyle mücadelede haber kuruluşları, sosyal medya platformları ve haber kaynakları ile resmî kurumların üzerine düşen görevler bulunmaktadır. Haber kuruluşları kontrol mekanizmalarını yeni medyaya uygun şekilde düzenleme ve yeni birimler oluşturma yoluna gitmesi gerekmekte ancak birçok yazılı ve görsel medya kuruluşu bu yaklaşımdan uzaktır. Yeni medyada bu görevi yine kullanıcılar ve özellikle doğrulama platformları gerçekleştirmektedir. Türkiye'de sosyal medyada viral olan şüpheli içerikleri araştıran Teyit, Malumatfurus, Doğruluğu Ne?, Doğruluk Payı, Yalansavar ve Günün Yalanları adlı doğrulama girişimleri bulunmaktadır.

Üç büyük sosyal medya platformu Facebook, Twitter ve Instagram ile özel mesajlaşma uygulaması Whatsapp, yanlış bilgiyle mücadele için kullanıcılarını şikâyet mekanizmalarına yönlendirme, yanlış ve sahte içerikleri kaldırma ya da etkileşimini sınırlandırma, bu içerikleri üreten kullanıcıları engelleme gibi denetim yöntemleri uygulamaktadır. Ancak bu yöntemler halen sorunun çözülmesini sağlamamıştır. Çünkü sahte haberler doğru haberlerden 6 kat daha hızlı yayılmakta ve 10 kat daha fazla kullanıcıya ulaşmaktadır (Vosoughi, Roy, \& Aral, 2018).

\section{ILLETISSIM FAKÜLTESİ ÖĞRENCILLERININ SOSYAL MEDYA KULLANIMI VE SAHTE/YALAN HABERLERE YÖNELİK GÖRÜŞLERİ}

Çalışmanın uygulama bölümünde iletişim fakültesi öğrencilerinin sosyal medya kullanımı ve sahte/yalan haberlere yönelik görüş ve davranışlarının belirlenmesi amacıyla yapılan saha araştırmasının bulgularına yer verilmiştir.

\subsection{Metodoloji}

Bu bölümde araştırmanın uygulanması ve katılımcıların seçimi, ölçüm araçları, veri toplama ve kullanılan istatistiksel analizlere ilişkin başlıklar bulunmaktadır.

\subsection{Katılımcıların Seçimi ve Araştırmanın Uygulanması}

Araştırmanın evrenini Selçuk Üniversitesi İletişim Fakültesi öğrencileri oluşturmaktadır. Bu bağlamda çalışmanın parametrik bir tasarıma sahip olduğu söylenebilir. Öğrencilerin farklı bölüm ve sınıflarda öğrenim gördüklerinden hareketle, tek başına basit tesadüfi (rastlantılı) örneklem tekniği kullanılmamıştır. Farklı bölüm ve sınıflarda bulunan öğrenci sayılarının evrendeki ağırlıklarına göre örneklemde temsil edilmesi fikrinden hareketle 
örneklem seçiminde “Küme Örneklemi” yöntemi de ayrıca kullanılmıştır. Küme örneklem tekniği içerisinde ayrıca örneklem seçiminde amaçlı ve katmanlı tekniklere de başvurulmuştur. Araştırmada veri toplama yöntemi olarak, yüz yüze anket yöntemi kullanılmıştır. Anket formunun verilmesi sırasında, gerekli açıklamalar yapılmıştır. Bu bağlamda 313 öğrenci ile 2020 yılı Şubat ayı içerisinde yüz yüze anket yapılmıştır.

\subsection{Soru Formu ve Ölçüm Araçları}

Soru formu, öğrencilerin kitle iletişim araçları/sosyal medya kullanımı ve yalan/sahta haberlere ilişkin davranışlarını ortaya koymayı amaçlamıştır. Bu çerçevede katılımcılara, ikisi kitle iletişim araçlarını kullanım davranışları, üçü sosyal medya araçlarını kullanım davranışları ve dördü de yalan haberler ile ilgili olmak üzere toplam 9 soru yöneltilmiştir. Son bölümde ise demografik sorular yer almaktadır. Söz konusu sorular, literatür taraması ve ilgili araştırma bulgularından yola çıkarak bizzat araştırmacılar tarafından hazırlanmıştır. Çalışmanın geçerliliği yüzey geçerliliği ile sağlanmıştır. Ayrıca, haberlerin takip edildiği sosyal medya platformları ile sosyal medya araçlarına güven düzeyi arasındaki tutarlı sonuçlar, çalışmanın yapı geçerliliğine de sahip olduğunu ortaya koymaktadır.

\subsection{Kullanılan İstatistiksel Analizler}

Katılımcılardan elde edilen verilerin girişi, SPSS 17.0 adlı program aracılığıyla yapılıış ve araştırma sorularını yanıtlamak için uygun istatistiksel analizler uygulanmıştır. Çalışma betimleyici bir araştırtma desenlemesine sahip olduğu için, betimleyici istatistikler (çoklu frekans analizi, merkezi eğilim istatistikleri), bağımsız örneklem testi ve çapraz tablo analizleri uygulanmıştır.

\subsection{Bulgular ve Yorum}

Çalışmanın bu bölümünde yapılan saha araştırması sonucu elde edilen bulgular ve yorumlara yer verilmiştir. Saha uygulamasının ilk bölümünde öğrencilerin kitle iletişim araçlarını ve sosyal medya platformlarını kullanım alışkanlıkları belirlenmeye çalışılmıştır. Bu alışkanlıklarla cinsiyet arasındaki ilişkiye de analizlerde yer verilmiştir.

Tablo 1: Haberlerin takip edildiği kitle iletişim araçları

\begin{tabular}{|l|c|}
\hline Kitle iletişim aracı & Ortalama \\
\hline 1.Televizyon & 2,36 \\
\hline
\end{tabular}




\begin{tabular}{|l|c|}
\hline 2. Gazete & 1,42 \\
\hline 3.Internet Haber Siteleri & 3,63 \\
\hline 4.Sosyal Medya & 4,37 \\
\hline 5.Radyo & 1,40 \\
\hline
\end{tabular}

İletişim fakültesi öğrencilerinin haberleri takip ettiği kitle iletişim araçlarının başında sosyal medyanın olduğu görülmektedir. İkinci sırada internet haber siteleri yer alırken, geleneksel medya araçlarından televizyon üçüncü tercih edilen araç olurken, gazete ve radyo ise en düşük takip edilen araçlar olarak belirlenmiştir.

Tablo 2: Haberlerin takip edildiği sosyal medya platformları

\begin{tabular}{|l|c|}
\hline Sosyal medya platformu & Ortalama \\
\hline 1.Instagram & 4,14 \\
\hline 2. Whatsapp & 3,38 \\
\hline 3.Twitter & 3,01 \\
\hline 4.Facebook & 1,46 \\
\hline
\end{tabular}

Öğrencilerin haber almak için tercih ettiği sosyal medya platformlarının başında İnstagram yer almaktadır. Whatsapp'ın haber alma platformu olarak ikinci sırada, Twitter'ın ise üçüncü sırada yer aldığı görülmektedir. Facebook ise öğrencilerin haber takibinde son tercihi olmuştur.

Tablo 3: Doğruluğundan şüphe duyulan haberlerin konuları

\begin{tabular}{|l|l|}
\hline Haber türüi & Yüzde \\
\hline 1. Siyaset & $\% 23$ \\
\hline 2. Güvenlik, Polis, Adliye & $\% 11,8$ \\
\hline 3. Kültür-sanat & $\% 17,2$ \\
\hline 4. Diş Politika-Dünya Haberleri & $\% 14,2$ \\
\hline 5.Bilim-teknoloji & $\% 13,3$ \\
\hline 6.Ekonomi & $\% 6.8$ \\
\hline 7. Sağlik & $\% 8,3$ \\
\hline 8. Spor & $\% 4,4$ \\
\hline 9. Sinema & $\% 0,1$ \\
\hline
\end{tabular}




\begin{tabular}{|l|l|}
\hline 10. Magazin & $\% 0,9$ \\
\hline
\end{tabular}

İletişim fakültesi öğrencilerinin en çok hangi haberlerin doğruluğundan daha çok şüphe duydukları sorulmuş, ilk sırada siyaset haberleri (\%23) cevabı olduğu tespit edilmiştir. İkinci sırada kültür-sanat $(\% 17,2)$ olduğu görülürken, onu dış politika $(\% 14,2)$, bilim ve teknoloji $(\% 13,3)$ ve sağlik haberleri $(\% 8,3)$ takip etmektedir. En az takip edilen haber türü ise magazin haberleri olmuştur.

Tablo 4: Sosyal medya platformlarına duyulan güven

\begin{tabular}{|l|c|}
\hline Sosyal medya platformu & Ortalama \\
\hline 1.Instagram & 2,63 \\
\hline 2. Whatsapp & 2,30 \\
\hline 3.Twitter & 3,00 \\
\hline 4.Facebook & 1,40 \\
\hline
\end{tabular}

Öğrencilerin haber açısından sosyal medya platformlarına ne kadar güvendiğinin belirlenmesi amacıyla sorulan soruya ilk sırada Twitter cevabı verilmiştir. Haber açısından ikinci güvenilir platform İnstagram olurken Whatsapp üçüncü, Facebook ise son sırada yer almıştır.

Tablo 5: Sosyal medya platformlarına duyulan güven düzeyinin cinsiyete göre farklılaşması

\begin{tabular}{|l|c|c|}
\hline \multirow{2}{*}{ Sosyal medya platformu } & \multicolumn{2}{|c|}{ Ortalama } \\
\cline { 2 - 3 } & Kadın & Erkek \\
\hline 1.Instagram & 2,80 & 2,46 \\
\hline 2. Whatsapp & 2,42 & 2,18 \\
\hline 3.Twitter & 3,15 & 2,82 \\
\hline 4.Facebook & 1,24 & 1,54 \\
\hline
\end{tabular}

Sosyal medya platformlarına duyulan güven düzeyi cinsiyete göre anlamlı biçimde farklılaşmaktadır. Kadın öğrencilerin İnstagram ve Twitter'a haber açısından erkeklere oranla daha fazla güvendiği belirlenirken, erkeklerin Facebook'u daha güvenilir bulduğu belirlenmiştir. Whatsapp'a duyulan güven düzeyi ise cinsiyet göre anlamlı biçimde farklılık göstermemiştir. 
Tablo 6: Kitle iletişim araçlarının taraflılık düzeyi

\begin{tabular}{|l|c|}
\hline Kitle iletişim aracı & Ortalama \\
\hline 1.Televizyon & 1,67 \\
\hline 2. Gazete & 1,87 \\
\hline 3.Internet Haber Siteleri & 2,46 \\
\hline 4.Sosyal Medya & 2,78 \\
\hline 5.Radyo & 2,55 \\
\hline
\end{tabular}

İletişim fakültesi öğrencilerinin kitle iletişim araçlarının haber açısından taraflılık düzeyleriyle ilgili görüşlerine yönelik testin sonuçlarına bakıldığında, en taraflı bulunan araçların televizyon ve gazete olduğu, sosyal medya ve internet haber sitelerinin daha az taraflı bulunan araçlar olduğu görülmektedir. Radyonun da tarafsız bulunduğu ancak haber için yaygın ve önemli bir araç olmaması bu sonucu etkilediği düşünülmektedir.

Tablo 7: Sosyal medyada haber paylaşma sıklı̆̆1

\begin{tabular}{|l|c|}
\hline Paylaşım aralı̆̆ı & Ortalama \\
\hline 1.Her gün & $\% 7$ \\
\hline 2. Günde birkaç kez & $\% 5,8$ \\
\hline 3.Haftada bir & $\% 11,2$ \\
\hline 4.Nadiren & $\% 46,3$ \\
\hline 5.Hiç paylaşmam & $\% 26,8$ \\
\hline
\end{tabular}

İletişim fakültesi öğrencilerinin ilgisini çeken haberleri sosyal medyada paylaşma sıklığıyla ilgili sonuçlara bakıldığında, öğrencilerin yüzde 46,3'ünün nadiren paylaşım yaptığını belirttiği, hiç haber paylaşmayanların oranının ise yüzde 26,8 olduğu görülmektedir. Hergün haber paylaşanların oranı ise yüzde 7 olarak belirlenmiştir.

Tablo 8: Kapalı mesajlaşma uygulamaları ve haber paylaşma sıklı̆̆1

\begin{tabular}{|l|l|}
\hline Kapalı mesajlaşma uygulaması & Ortalama \\
\hline 1.Facebook & 1,17 \\
\hline 2.Messenger & 1,21 \\
\hline 3.DM & 2,73 \\
\hline 4.Whatsapp & 2,86 \\
\hline
\end{tabular}


Öğrencilere, arkadaşları ya da herkesin görebileceği şekilde haber paylaşma davranışlarına yönelik sorunun yanı sıra kapalı mesajlaşma uygulamalarında haber paylaşma sıklıkları da sorulmuştur. Haber paylaşmak için en sık kullanılan aracın Whatsapp olduğu görülürken, farklı uygulamaların özel mesaj bölümlerinin ikinci sırada tercih edildiği belirlenmiştir.

Tablo 9: Sosyal medyada haber paylaşma sıklığının cinsiyete göre farklılaşması

\begin{tabular}{|l|l|l|}
\hline Sosyal medya platformu & \multicolumn{2}{|c|}{ Ortalama } \\
\cline { 2 - 3 } & Kadın & Erkek \\
\hline Hiç haber paylaşmayanlar & $\% 39$ & $\% 61$ \\
\hline Günde birkaç kez haber paylaşanlar & $\% 61,1$ & $\% 38,9$ \\
\hline
\end{tabular}

Sosyal medyada haber paylaşma sıklığı cinsiyete göre test edildiğinde, hiç haber paylaşmayan öğrencilerin yüzde 39'unun kadın, yüzde 61'inin ise erkek olduğu görülmüştür. Günde birkaç kez haber paylaştığını belirten öğrencilerin ise yüzde 61'inin kadın, yüzde 38,9'unun ise erkek olduğu tespit edilmiştir.

Saha uygulamasının ikinci bölümünde öğrencilerin sahte haberlere yönelik görüşlerini belirleme amacıyla sorular yöneltilmiştir. Sahte haberlere maruz kalıp kalmadıkları, bu haberlerin türü, sahte haberlere inanmanın altında yatan sebepler tespit edilmeye çalışılmıştır.

Tablo 10: Sosyal medya ve sahte habere maruz kalma

\begin{tabular}{|l|l|l|}
\hline Sahte haberle karşılaştınız mı? & Evet & Hayır \\
\cline { 2 - 3 } & $\% 97,4$ & $\% 2,6$ \\
\hline
\end{tabular}

Selçuk Üniversitesi İletişim Fakültesi öğrencilerinin yüzde 97,4'ü sosyal medyada sahte/yalan haberle karşılaştığını belirtmiştir. Karşılaşmadığını ifade edenlerin oranı ise yüzde 2,6 olmuştur.

Tablo 11: Sosyal medya platformlarında sahte/yalan haber yayınlanma sıklı̆̆1

\begin{tabular}{|l|l|}
\hline Sosyal medya platformu & Ortalama \\
\hline 1.Instagram & 3,45 \\
\hline 2. Whatsapp & 2,88 \\
\hline 3.Twitter & 3,05 \\
\hline 4.Facebook & 3,63 \\
\hline
\end{tabular}


Sosyal medya platformlarının hangisinde sahte/yalan haberlerin daha sık yayınladığı konusunda görüşleri sorulan öğrenciler, ilk sırada Facebook’u gösterirken, İnstagram ikinci, Twitter ise üçüncü sırada yer almıştır. Son sırada Whatsapp'ın olduğu görülmektedir.

Tablo 12: Sahte/yalan haber yayınlanma sıklığının cinsiyete göre farklılaşması

\begin{tabular}{|l|l|l|}
\hline \multirow{2}{*}{ Sosyal medya platformu } & \multicolumn{2}{|c|}{ Ortalama } \\
\cline { 2 - 3 } & Kadın & Erkek \\
\hline 1.Instagram & 3,33 & 3,59 \\
\hline 2. Whatsapp & 2,89 & 2,89 \\
\hline 3.Twitter & 2,86 & 3,24 \\
\hline 4.Facebook & 3,72 & 3,55 \\
\hline
\end{tabular}

Sosyal medya platformlarında karşılaşılan sahte haberlerin sıklığı cinsiyete göre platformlar arasında farklı düzeyde anlamlılık göstermiştir. Erkek öğrencilerin kadınlara oranla İnstagram ve Twitter'da daha fazla sahte haberle karşılaştıklarını belirttiği görülmektedir. Facebook ve Whatsapp açısından anlamlı bir ilişki bulunamamıştır.

Tablo 12: Kullanıcıların sahte haberlere inanma sebepleriyle ilgili görüşler

\begin{tabular}{|l|l|}
\hline Sahte haberlere inanma sebepleri & Yüzde \\
\hline 1.Araştırma yapmaktan kaçınma & $\% 29,2$ \\
\hline 2. Siyasi kutuplaşma & $\% 26,6$ \\
\hline 3. Gerçeklerden çok duygu ve inançların ön planda tutulması & $\% 23,4$ \\
\hline 4.Haber kaynaklarına ve habercilere güven duyulması & $\% 4,5$ \\
\hline 5.Medya okuryazarlığı eksikliği & $\% 7,7$ \\
\hline 6.Kitap okuma alışkanlığının olmaması & $\% 3,2$ \\
\hline 7.Yalan/sahte haberlerin profesyonelce hazırlanması & $\% 2,2$ \\
\hline 8.Yalan/sahte haberlerin doğruluğuyla ilgili bilgilerin azlığ1 & $\% 3,2$ \\
\hline
\end{tabular}

İletişim fakültesi öğrencileri, insanların internet ve sosyal medyadaki sahte/yalan haberlere en çok $(\% 29,2)$ "Araştırma yapmaktan kaçındıkları" için inandıklarını belirtmiştir. İkinci inanma sebebi ise yüzde 26,6 ile "siyasi kutuplaşma” olarak gösterilirken, "gerçeklerden çok duygu ve inançların ön planda tutulması"nın da sahte haberlere inanılmasının önemli nedenlerinden biri olduğunu belirtilmiştir. Medya okur-yazarlığ eksikliği önemli bir neden olarak görülmezken $(\% 7,7)$, yine sahte haberlerin profesyonelce hazırlanması, kitap okuma 
alışkanlığının olmaması, sahte haberlerin doğruluğuyla ilgili bilgilerin azlığı ve haber kaynaklarına güven duyulması gibi nedenler inanma sebepleri arasında alt siralarda gösterilmiştir.

\section{SONUÇ}

Sahte/yalan haber ve yanlış bilgi sorunu, yeni medyanın kitlesel ve kişiler arası iletişimin başat araçlarından biri olmasıyla birlikte enformasyon sisteminin önemli problem alanlarından biri haline gelmiştir. Özellikle gençlerin sıklıkla kullandığı mobil araçlar ve sosyal medya platformlarında, kullanıcının içerik üreticisi olması kontrolsüz bir haber üretim ve akışının ortaya çıkmasına neden olmuştur.

$\mathrm{Bu}$ bağlamda üniversite öğrencilerinin sahte haber ve yanlış bilgi sorunuyla ilgili görüşlerinin ortaya konması amacıyla yapılan betimleyici çalışmanın sonuçlarına bakıldığında, iletişim fakültesi öğrencilerinin haberleri büyük ölçüde sosyal medya ve internet haber sitelerinden takip ettiği görülmektedir. Haberlerin takip edildiği sosyal medya platformlarında, kullanım sıklığıyla doğru orantılı şekilde ilk sırada İnstagram'ın yer aldığı, Whatsapp'ın önemli bir haber edinme aracı haline geldiği görülmektedir.

Çalışmada anket uygulanan 313 öğrencinin yüzde 97,4'ü sosyal medyada sahte haberlerle karşılaştığını belirtmiştir. Yeni medya araçlarını kullananların neredeyse tamamı yalan haberlere maruz kalmaktadır. Geleneksel medyanın daha taraflı bulunmasına rağmen sahte haberlere yüksek oranda maruz kalınan sosyal medyaya güvenin fazla olması da önemli bir veri olarak ortaya çıkmaktadır.

Sahte haberlerin en çok karşılaşıldığg konunun siyaset ve dış politika konularında olduğu belirlenirken, kültür-sanat haberlerinde yalan haberle karşılaşma oranının yüksekliğgi dikkat çekmektedir. Sonuçlarda magazin haberleri çok düşük bir oranla yer almasına rağmen kültürsanat haberleriyle ilgili bu görüşün yüksekliği önemli bir veridir.

İletişim fakültesi öğrencileri sosyal medya platformlarına güven konusunda Twitter'1 ilk sıraya koyarken, İnstagram da güvenilir platformlar arasında gösterilmekte, Facebook ise en az güvenilir araç olarak belirlenmektedir. Twitter'ın haber ve siyasi gündem ilgili tercih edilen bir araç olması bu güvenin yüksek olmasını etkilediği düşünülmektedir. 
Güven ve cinsiyete göre farklılaşma arasında anlamlı ilişki bulunmuştur. Erkek öğrencilerin Facebook'a kadınlardan daha fazla, İnstagram ve Twitter'a ise kadınların daha fazla güvendiği belirlenmiştir.

Kitle iletişim araçlarının taraflılık düzeyiyle ilgili soruya verilen cevaplara bakıldığında, öğrenciler, geleneksel medya araçlarından gazete ve televizyonu daha taraflı gördüğü, sosyal medya ve internet haber sitelerini ise daha tarafsız bulduğu anlaşılmaktadır. Radyonun taraflılığının orta düzeyde çıkması ise aracın haber açısından yaygın kullanımınının olmamasıyla açıklanabilecektir.

Öğrencilerin sosyal medyada haber paylaşma sıklıklarının ölçülmesi amacıyla yapılan test, katılımcıların yaklaşık yarısının nadiren paylaşım yaptığını, yüzde 26'sının da hiç paylaşım yapmadığını göstermektedir. Her gün ya da günde birkaç kez haber paylaşanların oranı ise yüzde 10'larda kalmaktadır. Gençlerin genel olarak düşünce ve haber/bilgi paylaşımı konusunda aktif olmadığı anlaşılmaktadır. Kapalı mesajlaşma uygulamalarının haber paylaşımında daha çok tercih edildiği, bu konuda en sık kullanılan aracın ise Whatsapp olduğu belirlenmiştir.

Sosyal medya hesaplarında sık haber paylaşanlar ile hiç paylaşmayanların cinsiyete göre anlamlı farklılaştığı kadın öğrencilerin sık haber paylaşmaktan çekinmediği, hiç haber paylaşmayanlarda ise erkeklerin yüksek bir orana sahip olduğu, erkek öğrencilerin haber paylaşırken daha temkinli olduğu görülmüştür.

İletişim fakültesi öğrencileri, sahte haber ya da yanlış bilgi ile en çok karşılaştıkları platform olarak Facebook’u gösterirken, kriz dönemlerinde sıklıkla yanlış bilginin yayıldığı Whatsapp'ın en az sahte haberle karşılaşılan mecra olarak gösterilmesi dikkat çekmektedir.

$\mathrm{Bu}$ kategoride de güven ilişkisini doğrular nitelikte cinsiyet açısından anlamlı farklılıklar bulunmuştur. Erkek öğrenciler daha az güvendikleri İnstagram ve Twitter'da daha fazla sahte/yalan haberle karşılaştıklarını belirtmiştir.

Katılımcılar, insanların sahte haberlere inanmasının en önemli sebebinin araştırma yapmaktan kaçınma ve siyasi kutuplaşma olduğunu belirtmiştir. Üçüncü önemli sebep ise gerçeklerden çok duygu ve inançların ön planda tutulması gösterilmiştir. "Hakikat ötesi" kavramının açıklanmasında kullanılan bu ölçütün çalışmanın sonuçlarında da önemli oranda 
çıkması dikkat çekicidir. Medya okuryazarlığı eksikliğinin önemli bir sorun olarak görülmemesi de kayda değer bir veri olarak değerlendirilmektedir.

Yapılan çalışma, sahte haber sorunu konusunda önemli bir farkındalık olduğu, genelde üniversite özelde ise iletişim fakültesi öğrencilerinin, geleneksel medya ile yeni medya arasındaki farkları ortaya koyar nitelikte görüşler sergilediğini ortaya koymaktadır.

Haber tüketiminin yeni medyaya önemli ölçüde geçtiği bu enformasyon çağında, sahte haber sorununun çözümü için neler yapılması gerektiği, gençlerin ve genel sosyal medya kullanıcılarının bu konudaki beklentilerini belirleyecek nicel çalışmaların yanı sıra, sahte haberlere karşı gösterilen refleksler ve medya okuryazarlığı düzeyleri konusunda nitel araştırmalar yapılması alanda yapılacak çalışmalara katkı sağlayacaktır.

\section{EXTENDED ABSTRACT}

Traditional media is defined as newspaper, television, such as media tools in the long term is in the center of important ethical issues is located between and incorrect information manipulation, disinformation, propaganda, defined the facts of asparagus in the form of news, the media, the "renewal" continues to be discussed by taking new forms.

The phrase "Post Truth" (Keyes, 2019) used to describe the period when communication has changed significantly and the definition of truth has changed, has become an important definition for this new period in which truth is judged by evidence, not knowledge, but perception, point of view, the relationship between benefit and harm. In his work of the same name as the definition, Keyes notes that "truth has been replaced by believability" in today's world, while focusing on the causes of lies and deception throughout human history. Cyberspace, with its structure that makes it easier to lie and spread, has become an "ethics-free zone" where fraud is met with incentives, not sanctions (Keyes, 2019, s. 9, 259).

With personalized news applications, users who are not exposed to unwanted news can realize their desire to create an alternative media space. However, this process causes the abandonment of traditional methods, weakening or even disappearing of fact checking processes, and the use of the field for malicious purposes increases political and ideological polarization. 
International organizations, non-governmental organizations, governments and social media platforms place the fight against disinformation among their priorities in communication policies. Every year, Facebook pays millions of dollars to the fact checking organization for the detection of fake news on its site (Rupar, 2019).

The deliberate production and dissemination of misinformation is called disinformation as a result of malicious use. The English phrase "Misinformation" means the emergence and dissemination of false information before it is known to be fabricated/false. Claire Wardle (Taş \& Taş, 2018, s. 195) has considered spoof news that is not intended to cause harm while not receiving news that is intended to be produced and disseminated without intent within the definition of fake news. Allcott and Gentzkow also (2017, s. 213) cite the deliberate production of news for the purpose of causing harm as an important defining criterion. Therefore, misinformation may be considered appropriate for a description that covers the entire area of communication, but the basic definitions and the direction of the discussions indicate that fake news and misinformation statements can be used to contain each other.

"Believable lies" can go beyond the credibility of news and manipulation of opinions in New Media and reach the dimensions that threaten the safety of people. The falsehood of the word "no one dies from a lie", which is often used in Turkish, is often confirmed. During the coronavirus (COVID-19) outbreak, approximately 800 people who drank fake alcohol to protect themselves from the disease died in Iran due to fake news reports (Güler, 2020). The U.S. priest who caught the virus and died because of conspiracy theories or beliefs by underestimating the disease and failing to comply with the precautions was also reflected in the news as an important example during this period (Boorstein).

The sharpening of ideological biases and polarization, politicization and the decline of traditional news sources trust the news, the reluctance of relative freedom that provides to users of the New Media Research (can be used without the need for real ID), digital media filters and algorithms that occurs as a result of them with echo chambers, is counted among the factors that increase the production and spread fake news.

A significant number of these factors we have mentioned point to the role of cognitive biases, biases and previous convictions in the consumption of media messages. 
The three major social media platforms, Facebook, Twitter and Instagram, as well as the private messaging app WhatsApp, use control methods such as directing users to complaint mechanisms to combat misinformation, removing false and fake content or limiting their interaction, blocking users from producing such content. However, these methods still have not solved the problem. Because fake news spreads 6 times faster than true news and reaches 10 times more users (Vosoughi, Roy, \& Aral, 2018).

In this study, a face-to-face survey was conducted with 313 students to determine the university students ' views on the problem of fake news and misinformation. At the end of the study, it is seen that the students of the Faculty of communication followed the news largely through social media and internet news sites, and that Instagram was the first place in the social media platforms where the news was followed, and that WhatsApp became an important news acquisition tool.

While it is determined that the most common subject of fake news is politics and foreign policy issues, the high rate of encounter with fake news in culture-art news is remarkable. Facebook is Instagram as the least reliable tool, while communication school students put Twitter first when it comes to trust social media platforms. The fact that Twitter is a preferred tool for dealing with News and the political agenda is thought to have influenced that confidence to be high.

The bias of the mass media when looking at answers to the question about the level of students from more traditional media from newspapers and TV-sided saw, the more neutral it is found that social media and internet news sites.

The test, which was meant to measure the frequency of students sharing news on social media, shows that nearly half of respondents rarely share, while 26 per cent never share. The proportion of people who share news every day or several times a day remains at 10 per cent. It is understood that young people are not active in thinking and sharing news/information in general. It has been determined that closed messaging applications are more preferred in news sharing, while Whatsapp is the most common tool.

Faculty of communication students point to Facebook as the platform where they most encounter fake news or misinformation, while WhatsApp, where misinformation is often spread during times of crisis, is often cited as the medium where fake news is encountered. 
Participants noted that the main reason people believe fake news is the avoidance of research and political polarization. The third important reason is to prioritize emotions and beliefs rather than facts. It is noteworthy that this criterion used to explain the concept of" Beyond truth " appears significantly in the results of the study. The lack of media literacy is not seen as a major problem and is considered noteworthy data.

News consumption is significantly to occurrence of the new media in this information age, the solution of the problem what needs to be done for fake news, young people and social media in general as well as quantitative studies to determine the expectations of users in this regard, fake news topics and about the reasons to believe in the field of qualitative research will contribute to the work to be done.

\section{KAYNAKÇA}

Alcott, H., \& Gentzkow, M. (2017). Social media and fake news in the 2016 election. Journal of Economic Perspectives, 31(2), 211-236.

Boorstein, M. (2020). Prominent Virginia pastor who said 'God is larger than this dreaded virus' dies of covid-19. Temmuz 17, 2020 tarihinde Washington Post: https://www.washingtonpost.com/religion/2020/04/13/virginia-pastor-church-diescoronavirus/ adresinden alınd 1

Cambridge Dictionary. (2019). Fake News. Mayıs 9, 2020 tarihinde Cambridge Dictionary: https://dictionary.cambridge.org/tr/s\%C3\%B6zl\%C3\%BCk/ingilizce/fake-news adresinden alınd 1

digitalreport.com.tr. (2020). Whatsapp'ta yönlendirilen mesajlar yüzde 70 azaldı. Ağustos 2, 2020 tarihinde Digital Report: https://digitalreport.com.tr/whatsappta-yonlendirilenmesajlar-yuzde-70-azaldi-teknoloji-13594/ adresinden alınd1

Dubois, E. (2018). The echo chamber is overstated: the moderating effect of political interest and diverse media. Communication, Information Technologies, and Media Sociology (CITAMS) Special Issue, 5(21), 729-745.

Foça, M. A. (2019). Sahte Haber Karnesi: Yerel Seçimler 2019. www.teyit.org (https://teyit.org/wp-content/uploads/2019/05/Rapor-YS-2019-1.pdf).

Full Fact, Africa Check, Chequedo. (2020). Who is most likely to believe and to share misinformation? Ağustos 5, 2020 tarihinde https://fullfact.org/media/uploads/whobelieves-shares-misinformation.pdf adresinden alındı 
Güler, B. (2020). Iran'da sahte içkiden ölenlerin sayısı 800'e yaklaştı. Haziran 22, 2020 tarihinde Anadolu Ajansı: https://www.aa.com.tr/tr/dunya/iranda-sahte-ickidenolenlerin-sayisi-800e-yaklasti/1822904 adresinden alınd1

Giampaglia, G. L., \& Menczer, F. (2018). Misinformation and biases infect social media, both intentionally and accidentally. May1s 19, 2020 tarihinde The Conversation: https://theconversation.com/misinformation-and-biases-infect-social-media-bothintentionally-and-accidentally-97148 adresinden alındı

Ünal, R., \& Taylan, A. (2017). Sağlık iletişiminde yalan haber-yanlış enformasyon sorunu ve doğrulama platformları. Atatürk İletişim Dergisi(14), 81-100.

Kılıç, S. (2020). Gündem Belirleme Kuramı bağlamında Twitter ve internet gazetelerinin karşılaştırılması: Hürriyet ve Milliyet Gazeteleri örneği. Selçuk İletişim, 13 (1), 91-129.

Kazaz, M., \& Akyüz, S. S. (2019). Sahte Haber. Konya: Literatürk.

Keyes, R. (2019). Hakikat ötesi çağ: Günümüz dünyasında yalancılık ve aldatma. İzmir: Deli Dolu.

Kocabay Şener, N. (2018). "Doğruluk Kontrol Merkezi” ve "Yalan Haber” kavramlarına ilişkin içeriklerin medyada yansımasının araştırılması. Akdeniz Üniversitesi İletişim Fakültesi Dergisi(29. Özel Sayıs1), 355-373.

Narin, B. (2018). Kişiselleştirilmiş çevrimiçi haber akışının yankı odası etkisi, filtre balonu ve siberbalkanizasyon kavramları çerçevesinde incelenmesi. Selçuk İletişim, 11(2), 232251.

Pomerantsev, P. (2019). How fake news conquered the world? Haziran 14, 2020 tarihinde vox.com: https://www.vox.com/world/2019/10/24/20908223/trump-russia-fake-newspropaganda-peter-pomerantsev adresinden alınd

Reuters Digital News Report, R. (2020). Ağustos 5, 2020 tarihinde Digital News Report: https://reutersinstitute.politics.ox.ac.uk/sites/default/files/202006/DNR_2020_FINAL.pdf adresinden alındı

Rupar, A. (2019). Facebook's controversial fact-checking partnership with a Daily Callerfunded website, explained. May1s 30, 2020 tarihinde www.vox.com: https://www.vox.com/2019/5/2/18522758/facebook-fact-checking-partnership-dailycaller adresinden alınd 1

Törnberg, P. (2018). Echo chambers and viral misinformation: Modeling fake news as complex contagion. PLoS ONE, 13(9), 1-21.

Taş, O., \& Taş, T. (2018). Host-hakikat çağında sosyal medyada yalan haber ve Suriyeli mülteciler sorunu. Galatasaray Üniversitesi İletişim Dergisi, 183-208.

twitter.com. (2020). Milli hesaplar yan yana. Eylül 22, 2020 tarihinde www.twitter.com: https://twitter.com/search?q=milli\%20hesaplar\%20yan\%20yana\&src=typeahead_click adresinden alındı 
Uğur, F. (2020). Sosyal medyada birlik; Millî Hesaplar Yan Yana. Ağustos 2020 tarihinde Türkiye Gazetesi: https://m.turkiyegazetesi.com.tr/yazarlar/fuat-ugur/613553.aspx adresinden alınd 1

Vosoughi, S., Roy, D., \& Aral, S. (2018). The spread of true and false news online. Science, 357(6380), 1146-1151.

Wardle, C. (2020). Bilgi düzensizliği çağı. C. Silverman içinde, Dezenformasyon ve Medya Manipülasyonu Üzerine Doğrulama El Kitabı (s. 9-15). European Journalism CenterTeyit. 